\title{
HUMAN FACTORS AND HOW THEY CONTRIBUTE TO HELICOPTER ACCIDENTS
}

\section{UDZIAŁ CZYNNIKA LUDZKIEGO W WYPADKACH LOTNICZYCH NA ŚMIGŁOWCACH}

\author{
Janusz Szymczak \\ Air Force Institute of Technology \\ Instytut Techniczny Wojsk Lotniczych \\ 01-494 Warszawa, Poland, ul. Księcia Bolesława 6 \\ e-mail: janusz.szymczak@itwl.pl
}

\begin{abstract}
The paper has been intended to present analysis of causes of air accidents of civilian and military helicopters in Poland. For comparison, the analysis of accidents of civil-aviation helicopters in the United States has been also provided. Special attention has been paid to human factors and contribution thereof to accidents in the helicopter aviation.

To conclude the paper, the most essential causes of air accidents have been discussed and preventive actions suggested with the aim of reducing the number of helicopter accidents and hence, increasing the flight safety level.
\end{abstract}

Keywords: flight safety, air accidents, human factor, preventive actions

Streszczenie: W artykule przedstawiono analizę przyczyn wypadków lotniczych śmigłowców lotnictwa cywilnego i wojskowego w Polsce. W celach porównawczych przytoczono statystykę wypadków na śmigłowcach lotnictwa cywilnego w USA. Szczególną uwagę zwrócono na udział czynnika ludzkiego w wypadkach lotnictwa śmigłowcowego. W zakończeniu artykułu omówiono główne przyczyny wypadków lotniczych oraz zamieszczono propozycje przedsięwzięć profilaktycznych mających na celu zmniejszenie liczby wypadków na śmigłowcach, a przez to podwyższenie poziomu bezpieczeństwa lotów.

Slowa kluczowe: bezpieczeństwo lotów, wypadki lotnicze, czynnik ludzki, profilaktyka 


\section{HUMAN FACTORS AND HOW THEY CONTRIBUTE TO HELICOPTER ACCIDENTS}

\section{Introduction}

Typical of last decades of the $20^{\text {th }}$ century and the beginning of the $21^{\text {st }}$ century is more and more common use of helicopters to perform numerous tasks in many and various areas of national economy and in the army. Helicopters remain in use in all geographical regions and under different climatic conditions, from the torrid through the temperate to the frigid zones.

Helicopters fly their tasks/missions during the day and/or night, under normal/adverse weather conditions. Characteristic of helicopters are both their VTOL (vertical take-off and landing) capability and low-level flights. The peculiar character of the helicopters usage and a wide variety of tasks performed under adverse conditions prove conducive to air accidents. Detailed investigation into causes of all air accidents allows many and various preventive actions to be undertaken to improve flight safety.

\section{Human factors in accidents of civil aviation helicopters in the United States}

In the early $1990 \mathrm{~s}$ of the $20^{\text {th }}$ century a detailed report on the safety of flying civil-aviation helicopters was published in the United States of America. The analysis includes 890 air accidents with helicopters engaged; the total time flown by these helicopters was more than 6.5 million hours.

One can assume that causes of air accidents, revealed basing on both the experience of operating a huge population of helicopters with very high total time flown, prove reliable and representative of the whole helicopter aviation throughout the world. Figures 1 and 2 illustrate the analysis of causes of air accidents, and shares of particular kinds of causes in the total number of air accidents. Fig. 1 shows the percentage distribution of causes of air accidents. The major portion of air accidents of helicopters occurred due to aircrew (pilots) errors. The number of 573 accidents amounted to 
$64.5 \%$ of all air accidents. Failures/damages to aeronautical systems were 'responsible' for $29.5 \%$ whereas adverse weather conditions for $6 \%$ of accidents. Fig. 2 shows the percentage distribution of the total number of accidents due to errors of flying staff, mainly pilots. The detailed analysis of errors made by helicopter aircrews (pilots) gives the following distribution thereof:

flying errors $-36.5 \%$, poor knowledge of aeronautical hardware $-29.5 \%$, problems in dividing attention $-15.1 \%$, unruliness of the aircrew $-10.3 \%$, physiological reasons $-3.2 \%$.

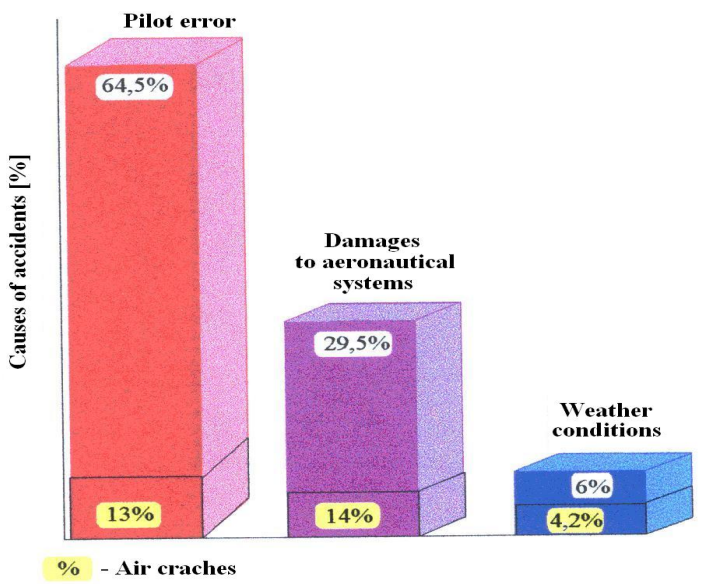

Fig. 1. Percentage distribution of different causes of air accidents, incl. $13 \%, 14 \%, 4.2 \%$ - air crashes

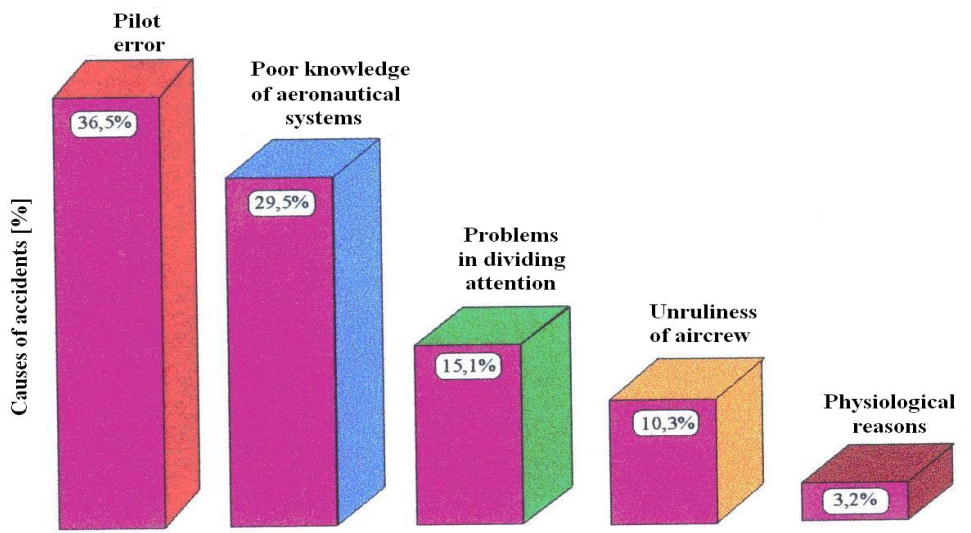

Fig. 2. Percentage distribution of the total of air accidents due to flying staff errors 
The above statistics shows that the percentage share of aircrew errors in the total number of air accidents is approximately $65 \%$, which is pretty high.

\section{Short analysis of air accidents in the civil aviation in Poland in $1990-97$}

In the years $1990-97$, in all types of civil aviation in Poland, 253 air accidents occurred, 17 fatalities (crashes), i.e. $6.7 \%$ of the total number of air accidents included. Out of this number, seven (7) accidents occurred to airplanes, four (4) to helicopters, four (4) to gliders, and two (2) to parachutes. Fatal accidents of helicopters amounted to $1.6 \%$ of the total number of air accidents.

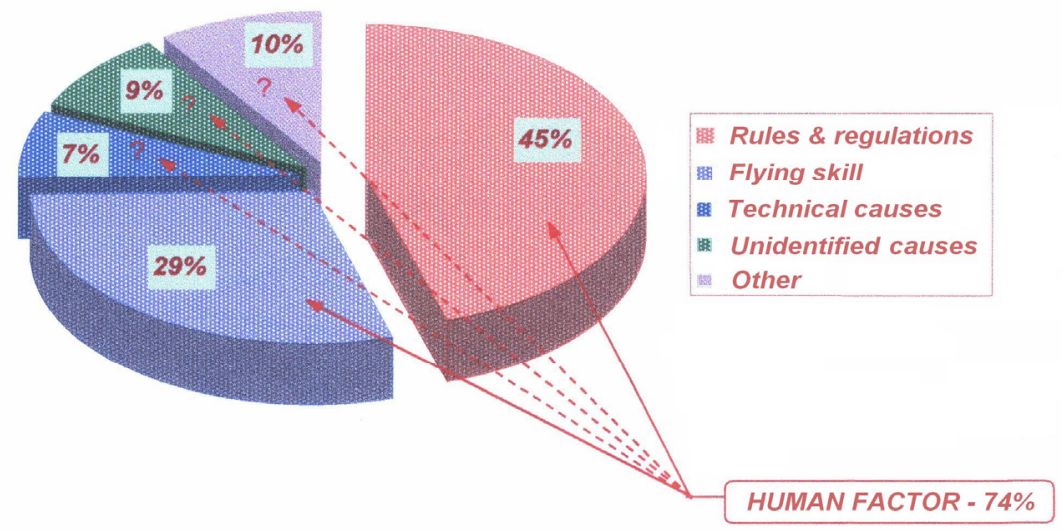

Fig. 3. Percentage distribution of causes of air accidents in civil aviation in Poland in $1989-97$

The distribution of causes of air accidents has been presented in Fig. 3. The percentage of the total of air accidents due to human factors was $74 \%$, including $45 \%$ due to flying errors, $7 \%$ due to engineering causes, $9 \%$ due to unidentified causes, and $10 \%$ due to other factors (birds, foreign matter, etc.).

\section{Short analysis of air accidents in the military helicopter aviation in Poland in 1990-2004}

In the years 1990-2004, in all Services of the Armed Forces of the Republic of Poland, 260 helicopter accidents and incidents occurred, including 23 fatalities and serious damages (i.e. 5 crashes and 18 severe damages/failures), which made up the total of $8.84 \%$ of all air accidents; 
crashes and damages/failures amounted to $1.92 \%$ and $6.92 \%$, respectively. The quantitative and percentage shares of particular causes of air accidents have been shown in Figures 4 and 5, respectively.
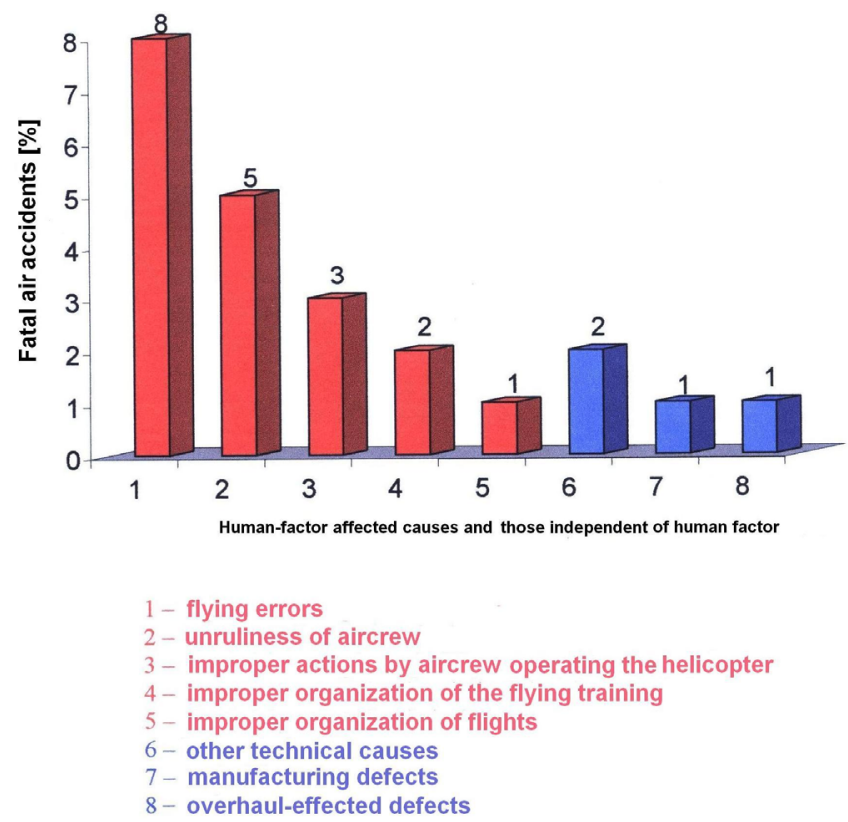

Fig. 4. Percentage distribution of fatal air accidents in military aviation in Poland in $1990-2004$

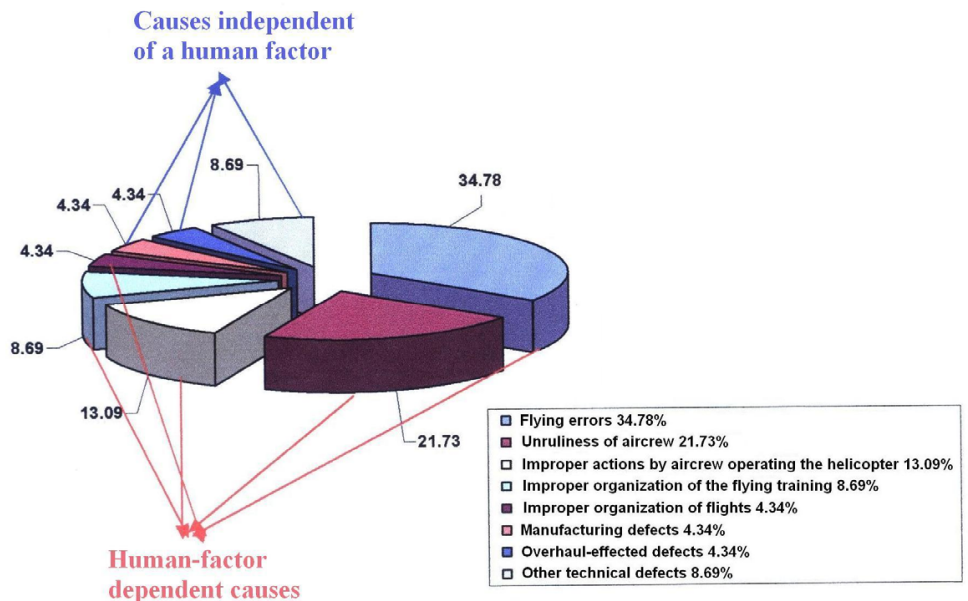

Fig. 5. Percentage distribution of causes of fatalities in military aviation in Poland in 1990 - 2004 
If the 23 fatal accidents are assumed 100\%, the percentages of particular causes of air accidents are as follows:

- Air accidents due to a human factor:

- flying errors - $34.78 \%$,

- unruliness of aircrew - $21.73 \%$,

- improper actions by the aircrew operating the helicopter $-13 \%$,

- improper organization of the flying training $-8.69 \%$,

- improper organization of flights $-4.34 \%$.

- Air accidents independent of a human factor:

- manufacturing defects $-4.34 \%$,

- overhaul-effected defects $-4.34 \%$,

- technical defects $-8.69 \%$.

The percentage share of human-factor induced fatal accidents is $82.6 \%$, whereas of those independent of the human factor $17.35 \%$.

\section{To recapitulate ...}

The analysis of causes of helicopter accidents proves the human factor predominates in the total of causes of fatal accidents and/or severe damages. In particular, the helicopter aircrew (pilot) are responsible for the majority of all accidents/incidents. Their share is estimated at $60 \%$ to $80 \%$, whereas the share of failures/damages to aeronautical systems/devices at approximately $30 \%$, and that of climatic/weather conditions - at about $10 \%$. The percentage of errors made by pilots in the flying technique are estimated at $30 \div 40 \%$, those attributable to poor knowledge of aeronautical systems/devices - at approximately $30 \%$. Problems in dividing attention cause about $15 \%$ of all accidents, whereas unruliness of aircrews approximately $10 \%$, improper organization of flights and the flying training give grounds for about $5 \div 10 \%$, and physiological reasons - for approximately $3 \%$ of all air accidents.

What proves conducive to errors made by the helicopter aircrew (pilot) is as follows:

- war-related stress,

- the type of mission to be flown and how difficult it is,

- flight organization,

- weather conditions,

- flying-skill deficiencies,

- improper workload sharing by aircrew members,

- improper attention distribution, 
- poor cockpit ergonomy,

- delayed actions or no action in emergencies,

- excess information (information overload),

- psychic effort and physical workload,

- fatigue,

- optical illusions, hallucinations,

- no control over the flight,

- poor health - disease.

\section{Preventive actions suggested}

To increase flight safety level, the contribution of a human factor to the airaccident occurrences should be reduced. Also, aeronautical systems should be improved all the time. Therefore, the following steps should be taken:

- to augment health requirements for pilots and other aircrew members,

- to increase the number of flight-simulator training hours, in particular - in emergencies,

- to increase the number of training hours in a helicopter simulator, in particular - flights in day, night, adverse and IFR conditions,

- to exactly and carefully prepare any mission to be flown,

- to increase frequency of checks of how a flight proceeds - by a flyingcontrol officer and the air traffic control (ATC) service,

- to improve ergonomy and pilot's comfort while working,

- to modernize instruments and low-altitude warning systems,

- to develop terrain and obstacle (power transmission lines, high chimneys, aerial cable railways, ski lifts, etc.) detection and early warning systems based on the Global Positioning System (GPS), the Enhanced GroundProximity Warning System (EGPWS), etc.

\section{References}

1. Statystyka wypadków lotniczych lotnictwa wojskowego $(1990 \div 2004)$, OBL Sił Powietrznych RP

2. Statystyka wypadków lotniczych lotnictwa cywilnego (1989:1997), materiały ZBL-GILC RP

3. NTSB analysis of helicopter accidents, Interavia, No. 2, 1982

4. Małachow, J.A.: Problemy Biezopastnosti Poliotow, No. 1, Moscow, 1984

5. Józef Żurek et al, Żywotność śmigłowców, Publ. by ITE-PIB, Radom, 2006 


\section{UDZIAŁ CZYNNIKA LUDZKIEGO W WYPADKACH LOTNICZYCH NA ŚMIGLOWCACH}

\section{Wstęp}

W ostatnich dziesięcioleciach XX wieku i na początku XXI wieku obserwuje się coraz powszechniejsze stosowanie śmigłowców do różnych zadań lotniczych w wielu dziedzinach gospodarki narodowej oraz w wojsku. Śmigłowce stosowane są we wszystkich strefach geograficznych i w różnych warunkach klimatycznych od tropiku aż po klimat polarny.

Zadania lotnictwa śmigłowcowego wykonywane są w dzień i w nocy, w zwykłych i trudnych warunkach atmosferycznych. Charakterystyczna właściwością śmigłowców jest ich zdolność pionowego startu i lądowania oraz loty na małych wysokościach. Specyfika stosowania śmigłowców oraz różnorodność realizowanych zadań lotniczych w trudnych warunkach sprzyja powstawaniu wypadków lotniczych (WL). Dokładne poznanie przyczyn wszystkich wypadków lotniczych umożliwia podjęcie działań oraz opracowanie przedsięwzięć profilaktycznych mających na celu poprawę bezpieczeństwa lotów.

\section{Udzial czynnika ludzkiego w wypadkach lotniczych cywilnego lotnictwa śmigłowcowego w USA}

$\mathrm{Na}$ początku lat dziewięćdziesiątych $\mathrm{XX}$ wieku w USA opublikowano szczegółową analizę bezpieczeństwa lotów na śmigłowcach lotnictwa cywilnego. Analizą objęto 890 wypadków lotniczych (WL) śmigłowców, przy ogólnym ich nalocie wynoszącym ponad 6,5 miliona godzin.

Można przyjąć, że przyczyny wypadków ujawnione na podstawie doświadczeń eksploatacji dużej populacji śmigłowców i o bardzo dużym ich nalocie są wystarczająco reprezentatywne i wiarygodne dla całego lotnictwa śmigłowcowego w świecie. Analizę przyczyn WL i ich udział w ogólnej liczbie wypadków przedstawiono na wykresach rys. 1 i 2 . Na rys.1 pokazano rozkład przyczyn wypadków lotniczych w procentach. Przeważająca część wypadków lotniczych śmigłowców powstała $\mathrm{z}$ winy załogi (pilotów), tj. $573 \mathrm{WL}$, co stanowi 64,5\% wszystkich wypadków. Uszkodzenia techniki lotniczej stanowiły $29,5 \%$ wszystkich WL i $6 \% \mathrm{WL}$ powstało w trudnych warunkach meteorologicznych. 
Na rys. 2 przedstawiono procentowy rozkład liczby wypadków lotniczych spowodowanych błędami personelu latającego w tym głównie pilotów.

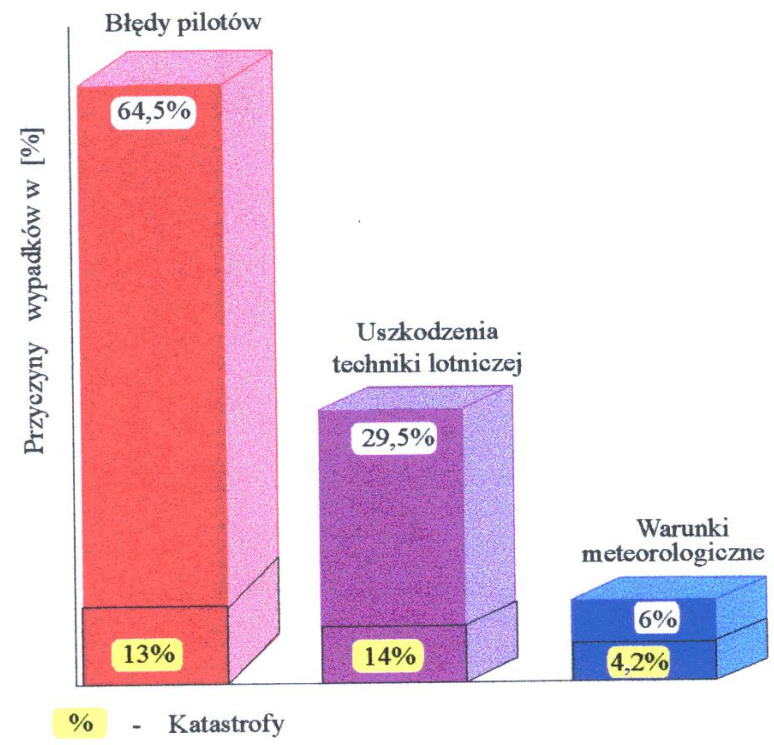

Rys. 1. Rozkład procentowy przyczyn wypadków lotniczych

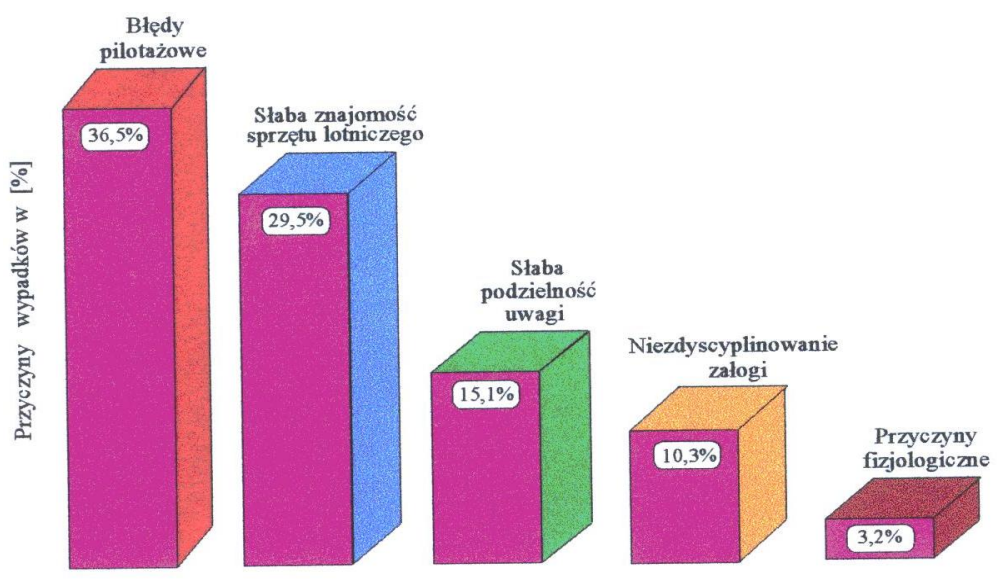

Rys. 2. Procentowy rozkład wypadków lotniczych spowodowanych błędami personelu latającego 
Z powyższego wynika, że udział błędów załogi w odniesieniu do ogólnej liczby wypadków lotniczych był duży i wynosił około 65\%.

$\mathrm{Z}$ analizy błędów popełnionych przez załogi (pilotów) śmigłowców wynika, że ich rozkład wygląda następująco:

- błędy pilotażu - 36,5\%,

- słaba znajomość sprzętu lotniczego - 29,5\%,

- niewłaściwa podzielność uwagi - 15,1\%,

- niezdyscyplinowanie załogi - 10,3\%,

- przyczyny fizjologiczne $-3,2 \%$.

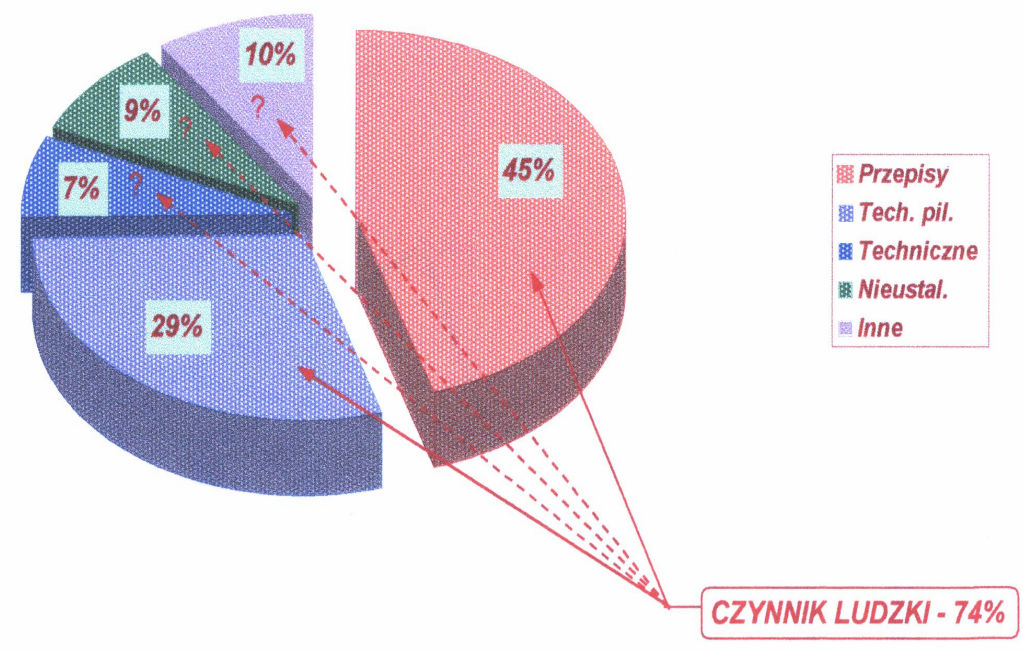

Rys. 3. Procentowy rozkład przyczyn wypadków lotniczych lotnictwa cywilnego w Polsce w latach 1989 $\div 1997$

\section{Krótka analiza wypadków lotniczych na lekkich statkach powietrznych w lotnictwie cywilnym w Polsce w latach 1990 - 1997}

We wszystkich rodzajach lotnictwa cywilnego w Polsce w okresie ośmiu lat, tj. w latach 1990-1997 zdarzyło się 253 wypadki lotnicze, w tym 17 ciężkich WL (katastrofy), co stanowi 6,7\% ogólnej liczby WL. Z tego 7 ciężkich WL wystąpiło na samolotach, 4 na śmigłowcach, 4 na szybowcach 
i 3 na spadochronach. Wypadki ciężkie na śmigłowcach stanowiły 1,6\% ogólnej liczby WL.

Procentowy udział czynnika ludzkiego we wszystkich przyczynach WL wynosił $74 \%$, w tym technika pilotowania $29 \%$, przyczyny techniczne stanowiły $7 \%$, przyczyny nieustalone $9 \%$ i $10 \%$ inne (ptaki, ciała obce).

\section{Krótka analiza wypadków lotniczych w wojskowym lotnictwie śmigłowcowym w latach 1990-2004}

W latach 1990-2004 we wszystkich rodzajach Sił Zbrojnych RP na śmigłowcach zdarzyło się 260 wypadków lotniczych, z czego $23 \mathrm{WL}$ to katastrofy i awarie, które stanowią 8,84\% ogólnej liczby WL w tym 5 katastrof i 18 awarii. Katastrofy stanowiły 1,92\%, a awarie 6,92\% ogólnej liczby WL.

Rozkład liczbowy i procentowy przyczyn wypadków lotniczych przedstawiono na rys. 4 i 5 .

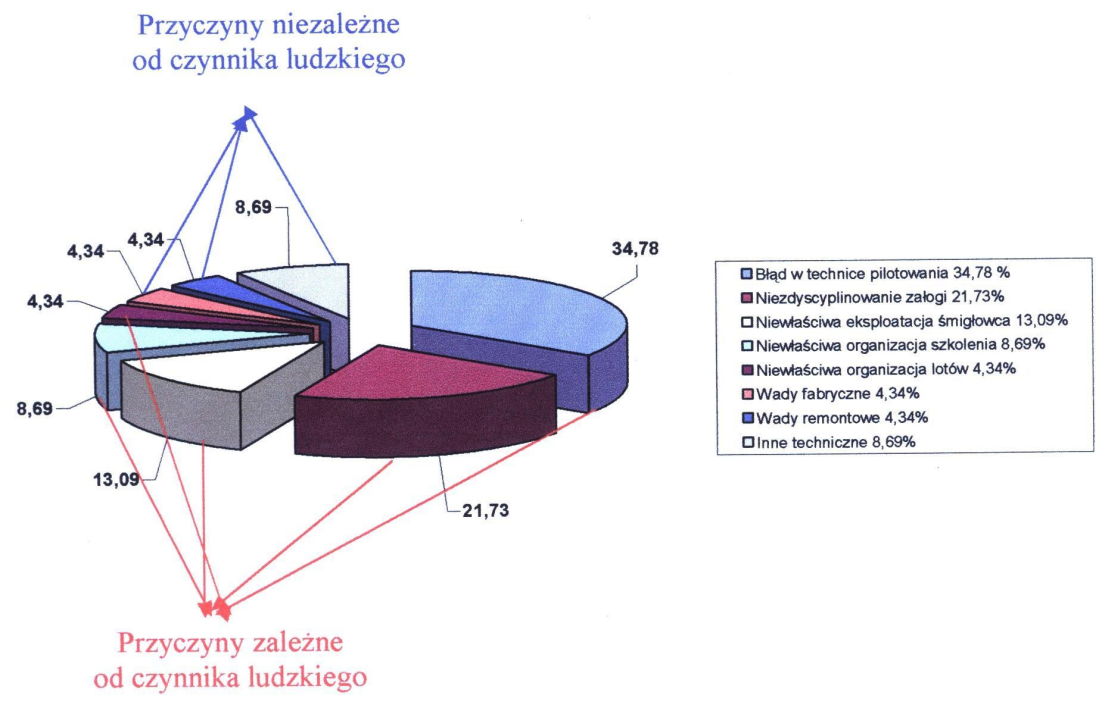

Rys. 4. Rozkład liczbowy przyczyn ciężkich wypadków lotniczych lotnictwa wojskowego w Polsce w latach 1990 $\div 2004$ 


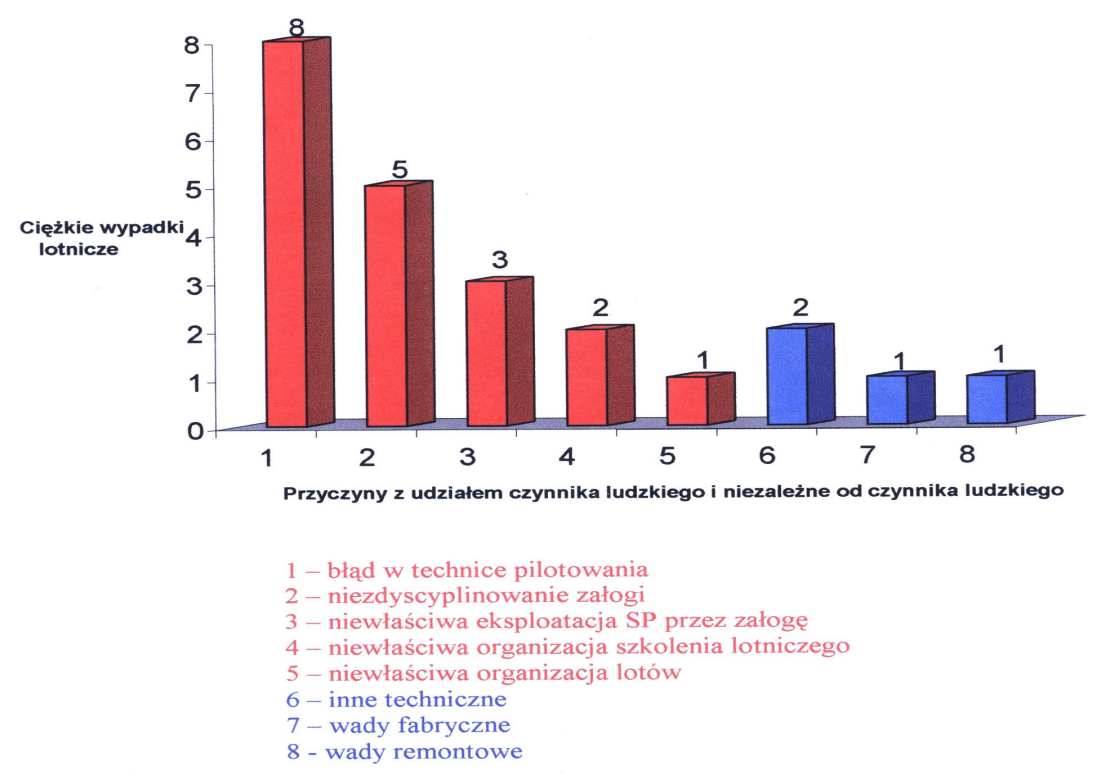

Rys. 5. Rozkład procentowy przyczyn ciężkich wypadków lotniczych w lotnictwie wojskowym w Polsce w latach 1990 $\div 2004$

Jeżeli przyjmiemy liczbę dwudziestu trzech ciężkich WL za 100\%, to rozkład procentowy ich przyczyn przedstawia się następująco:

Wypadki lotnicze zależne od czynnika ludzkiego:

- błąd w technice pilotowania - 34,78\%,

- niezdyscyplinowanie załogi - 21,73\%,

- niewłaściwa eksploatacja śmigłowca przez załogę - 13\%,

- niewłaściwa organizacja szkolenia lotniczego - 8,69\%,

- niewłaściwa organizacja lotów - 4,34\%.

Wypadki lotnicze niezależne od czynnika ludzkiego:

- wady fabryczne $-4,34 \%$,

- wady remontowe $-4,34 \%$,

- inne techniczne $-8,69 \%$.

Udział czynnika ludzkiego w przyczynach ciężkich WL wynosi 82,6\%, a udział procentowy przyczyn niezależnych od człowieka wynosi 17,35\%. 


\section{Podsumowanie}

$\mathrm{Z}$ analizy badań przyczyn wszystkich wypadków lotniczych na śmigłowcach wynika, że dominujący jest wpływ czynnika ludzkiego na powstanie ciężkich wypadków lotniczych, a zwłaszcza błędy popełnione przez załogę (pilota) śmigłowca, których udział wynosi od $60 \%$ do $80 \%$, uszkodzenia techniki lotniczej stanowią około $30 \%$ WL, a wpływ warunków klimatycznych i meteorologicznych wynosi od $6 \%$ do $10 \%$ przyczyn WL. Błędy popełnione przez pilotów w technice pilotowania wynoszą około $30 \% \div 40 \%$, a wynikające ze słabej znajomości sprzętu lotniczego około $30 \%$, brak podzielności uwagi stanowi około 15\% przyczyn WL, niezdyscyplinowanie załogi jest przyczyną od $10 \%$ do $20 \%$ WL, niewłaściwa organizacja lotów oraz szkolenia lotniczego jest przyczyną około $5 \% \div 10 \% \mathrm{WL}$, a przyczyny fizjologiczne stanowią około $3 \% \mathrm{WL}$.

Na popełnianie błędów przez załogę (pilota) śmigłowca wpływ mają takie czynniki jak:

- stres wojenny,

- rodzaj i stopień trudności zadania lotniczego,

- organizacja lotów,

- trudne warunki meteorologiczne,

- braki w wyszkoleniu lotniczym,

- brawura,

- niewłaściwy podział zadań wśród załogi,

- niewłaściwe rozłożenie uwagi,

- niewłaściwa ergonomia kabin,

- spóźnione działanie lub brak działania w sytuacjach awaryjnych,

- nadmiar (przeładowanie) informacji,

- obciążenie psychiczne i fizyczne,

- zmęczenie,

- złudzenia optyczne i halucynacje,

- brak kontroli nad lotem,

- słaby stan zdrowia - choroba. 


\section{Propozycje przedsięwzięć profilaktycznych}

W celu podwyższenia poziomu bezpieczeństwa lotów należy zmniejszyć wpływ czynnika ludzkiego na powstawanie wypadków lotniczych oraz doskonalić technikę lotniczą podejmując, następujące przedsięwzięcia:

- podwyższyć wymagania zdrowotne względem pilotów i innych członków załogi śmigłowców;

- zwiększyć liczbę godzin szkolenia na symulatorach, a zwłaszcza w przypadkach szczególnych - awaryjnych;

- zwiększyć liczbę godzin szkolenia na śmigłowcach, zwłaszcza $\mathrm{w}$ trudnych warunkach $\mathrm{w}$ dzień i w nocy, według przyrządów w kabinie;

- dokładnie i szczegółowo przygotowywać realizację zadań lotniczych;

- zwiększyć częstotliwość kontroli przebiegu lotu, przez kierowników lotu i służby ruchu lotniczego;

- poprawić ergonomię i komfort pracy w kabinie;

- unowocześnić przyrządy i systemy ostrzegania o niebezpiecznej wysokości lotu;

- opracować system wczesnego ostrzegania o przeszkodach terenowych, jak: przewody linii energetycznych, wysokie kominy, kolejki linowe, wyciagi narciarskie itp. w oparciu o system Global Positioning System (GPS) i EGPWS.

Dr inż. SZYMCZAK Janusz. Specjalista w dziedzinie silników lotniczych zajmujący się eksploatacją silników lotniczych , badaniem przyczyn wypadków lotniczych oraz uszkodzeniami silników lotniczych. 40 lat służby w lotnictwie sił zbrojnych a w tym ponad 30 lat pracy w Instytucie Technicznym wojsk Lotniczych. 